\title{
Leptin Signaling in the Central Nervous System and the Periphery
}

\author{
Christian BJørbæk and Barbara B. Kahn
}

The Division of Endocrinology, Diabetes and Metabolism, Department of Medicine, Beth Israel Deaconess Medical Center and Harvard Medical School, Boston, Massachusetts 02215

\begin{abstract}
The discovery of leptin in 1994 has led to astonishing advances in understanding the regulation of energy balance in rodents and humans. The demonstration of leptin receptors in hypothalamic regions known to play critical roles in regulating energy intake and body weight has produced considerable excitement in the field. Most attention has focused on the central actions of leptin. The receptor is present in several populations of neurons that express specific appetite-regulating neuropeptides for which both expression and release are regulated by leptin. Recent advances show that central leptin action is not limited to influencing energy balance. Leptin regulates a broad variety of processes and behaviors, such as blood pressure, neuroendocrine axes, bone mass, and immune function. The cloning of leptin receptors also led to parallel studies examining their signaling capacities in mammalian cell lines. The long-form receptor regulates multiple intracellular signaling cascades, including the classic janus activating kinase-signal transducer and activator of transcription (JAK-STAT) pathway, consistent with belonging to the cytokine-receptor superfamily and the phosphoinositol-3 kinase and adenosine monophosphate kinase pathways. Progress has been made in understanding the role of individual signaling pathways in vivo and the mechanisms by which specific neuropeptides are regulated. Regulation of the pro-opiomelanocortin (pomc) and the thyrotropinreleasing hormone (trh) genes by leptin is particularly well understood. Novel players in negative regulation of central leptin receptor signaling have been identified and open the possibility that these may be important in the development of leptin resistance and obesity. While initial focus was on the central effects of leptin, important actions have been discovered in peripheral tissues. These include roles of leptin to directly regulate immune cells, pancreatic beta cells, adipocytes, and muscle cells. Recent elucidation of a new signaling pathway in skeletal muscle affecting fatty acid metabolism has implications for regulation of insulin sensitivity and glucose metabolism. Recent progress in understanding central and peripheral leptin receptor signaling provides potential new targets for anti-obesity and anti-diabetes drug development.
\end{abstract}

\section{Introduction}

Leptin, the polypeptide product of the $o b$ gene, acts on the brain to regulate energy balance (Elmquist et al., 1998a; Friedman et al., 1998; Schwartz et al., 2000). The hormone, which consists of 167 amino acid residues, is produced almost exclusively in adipose tissue. Consistent with the initial prediction of leptin being a secreted protein, due to the presence of a signal sequence (Zhang et al., 1994), leptin is indeed in the circulation of mice and humans at levels that 
correlate with the amount of fat tissue (Frederich et al., 1995; Maffei et al., 1995). The discovery that administering recombinant leptin to mice resulted in marked weight loss generated considerable excitement (Campfield et al., 1995; Halaas et al., 1995; Pelleymounter et al., 1995). The weight-reducing effect was restricted to adipose tissue without significantly affecting lean body mass. Early studies also showed that low doses of leptin, when administered directly into the brain ventricles of rodents, were effective in reducing food intake and body weight (Campfield et al., 1995; Stephens et al., 1995). Lack of functional leptin or leptin receptors in mice and humans results in morbid obesity (Zhang et al., 1994; Montague et al., 1997; Clement et al., 1998). These results combined argue that leptin is an adiposity signal that acts directly on the central nervous system (CNS) via receptors expressed at this site.

Interest in leptin initially focused on its centrally mediated weight-reducing effects and on the potential for using the leptin/leptin receptor axis to develop therapeutic drugs to treat obesity. The later finding that leptin resistance is present in all but a small subset of obese humans has diminished those hopes. More-recent studies have revealed additional pleiotrophic functions of leptin, including the ability to affect neuroendocrine function, the adaptive response to fasting, reproductive function, brain size, bone development, immune function, blood cell development, blood pressure, glucose homeostasis, fatty acid metabolism, and regulation of sensory nerve input and autonomic outflow. Although many of these processes are regulated by central actions of leptin, some are mediated via direct actions in the periphery.

Through expression cloning using mouse brain and by positional cloning of the $d b$ locus in mice, leptin receptors (ObR) were identified in late 1995 (Tartaglia et al., 1995) and early 1996 (Lee et al., 1996). Consistent with leptin having structural similarity with cytokines, ObR belongs to the cytokine receptor class I superfamily and is most-closely related to gp130, the signal-transducing membrane protein of the interleukin-6 (IL-6) signaling complex, the leukemia inhibitory factor (LIF) receptor, and the granulocyte colony-stimulating factor (G-CSF) receptor (Tartaglia et al., 1995). Five alternatively spliced isoforms of $\mathrm{ObR}(\mathrm{a}, \mathrm{b}, \mathrm{c}, \mathrm{d}, \mathrm{e})$ with different lengths of $\mathrm{C}$-termini have been identified in mice (Lee et al., 1996), with additional isoforms found in other species. This chapter will focus on the biology of the long leptin receptor $(\mathrm{ObRb})$, since this isoform is fully capable of activating intracellular signaling. Its importance is demonstrated by the fact that absence of ObRb causes morbid obesity in $d b / d b$ mice (Chen et al., 1996; Lee et al., 1996).

\section{Central Leptin Receptor Signaling}

\section{A. EXPRESSION OF LEPTIN RECEPTORS IN THE CNS}

Selective deletion of all leptin receptor isoforms in neurons leads to obesity in mice (Cohen et al., 2001), underscoring the importance of leptin action in the 
brain for regulating body weight. The short leptin receptor isoform, ObRa, is expressed in the brain, with the highest levels in the choroid plexus and in microvessels (Tartaglia et al., 1995; Mercer et al., 1996b; Bjorbaek et al., 1998b). There, it may play a role in leptin uptake or efflux from the cerebrospinal fluid and in receptor-mediated transport of leptin across the blood-brain barrier into the brain (Tartaglia et al., 1995; Hileman et al., 2000). However, not all studies support these possibilities (Kowalski et al., 2001). Less is known about biology of the other short membrane-bound isoforms also present in the brain (Guan et al., 1997; Hileman et al., 2002).

The long form, $\mathrm{ObRb}$, is highly expressed in selected nuclear groups in the rodent and human brain. Within the hypothalamus, dense mRNA expression is detected in the arcuate (ARC), dorsomedial (DMH), ventromedial (VMH), and ventral premamillary nuclei (PMV); moderate expression is found in the periventricular hypothalamic nucleus and lateral hypothalamic area (LHA); and evenlower levels exist in the paraventricular nucleus (PVH) (Mercer et al., 1996b; Fei et al., 1997; Elmquist et al., 1998b). Outside the hypothalamus, ObRb mRNA has been found in numerous sites, with particularly high levels in the thalamus and the Purkinje and granular cell layers of the cerebellum (Guan et al., 1997; Elmquist et al., 1998b; Mercer et al., 1998). Surprisingly, signaling capabilities of $\mathrm{ObRb}$ proteins located at these extrahypothalamic regions have not been reported (see below). However, since binding of ${ }^{125}$ I-leptin to brain sections containing some of these sites can be detected (Corp et al., 1998; Baskin et al., 1999a), leptin may not reach these regions from the circulation or ObRb may serve a novel function that has yet to be identified. In contrast, leptin administration into the bloodstream of rodents induces ObRb-dependent signaling in neurons located in the hypothalamus and in limited regions outside the hypothalamus (see below), strongly suggesting that these regions express functional $\mathrm{ObRb}$ proteins with access to circulating leptin and activate downstream signaling events. Specifically, using immunohistochemistry on brain sections from leptin-treated rats and mice, careful mapping studies have reported rapid and robust signal transducer and activator of transcription 3 (STAT3) activation (Hubschle et al., 2001; Hosoi et al., 2002; Muenzberg et al., 2003) and induction of c-Fos proteins (Elmquist et al., 1997; Elias et al., 2000) in hypothalamic regions. Although some discrepancies are noted, the main sites generally overlap well with those reported to contain ObRb mRNA, including the ARC, DMH, VMH, LHA, PMN, and PVH. Some differences among the studies can be explained by the fact that c-Fos is induced only in the subpopulation of neurons that is activated by leptin (Elmquist et al., 1997; Elias et al., 1999). Sensitive signaling assays for cFos and STAT3 activation also detected leptin-responsive sites in regions outside the hypothalamus; namely, the dorsal raphae (DR), the periaqueductal gray (PAG), and the parabrachial nucleus (PBN) located in the midbrain and the nucleus of the solitary tract (NTS) in the caudal brainstem 
(Figure 1). One report also demonstrates STAT3 activation in the piriform cortex (Hubschle et al., 2001), consistent with the presence of dense ObRb mRNA expression at this site (Elmquist et al., 1998b). However, as indicated previously, none of the immunohistochemical assays reported leptin-dependent signaling in the thalamus or cerebellum, which brings into question the presence of functional receptors at these sites. In contrast, striking progress has been made in understanding direct leptin action on neurons located in the ARC and the PVH.

\section{B. NEURONAL SIGNALING BY THE LEPTIN RECEPTOR}

Cell-based studies and in vivo experiments over the last 8 years have led to a relatively detailed understanding of regulation of intracellular signaling by the long form of the leptin receptor. Binding of leptin to its receptor results in rapid activation of intracellular JAK2 that is constitutively associated with conserved, membrane-proximal regions of ObRb (Ghilardi and Skoda, 1997). We demonstrated that this JAK2 activation leads to tyrosine phosphorylation of ObRb (Bjorbaek et al., 1997). The phosphorylation sites later were identified as amino acid residues 985 and 1138 (Li and Friedman, 1999; Banks et al., 2000), which provide binding motifs for src homology 2 (SH2)-domain containing proteins such as STAT3 and SH-2-domain-phosphotyrosine phosphatase (SHP-2) (Bjorbaek et al., 2000b). STAT3 proteins bind to Y1138, become tyrosine phosphorylated by JAK2, then dissociate and form dimers in the cytoplasm, finally translocating to the nucleus to regulate gene transcription. STAT3 activation is likely a crucial component in regulation of body weight by leptin, as specific knockout (KO) of the Y1138 residue of ObRb in mice results in severe obesity (Bates et al., 2003). Tyrosine 985 of ObRb binds SHP-2 and leads to activation of the extracellular signal-regulated kinase (ERK)1/2 pathway and induction of c-Fos expression in transfected cells (Banks et al., 2000; Bjorbaek et al., 2000b) (Figure 2).

Since leptin can activate phosphoinositol-3 kinase (PI3K) in non-neuronal tissues (Harvey et al., 2000; Zhao et al., 2002a), Niswender and colleagues (2001) examined possible regulation in the hypothalamus. They found a rapid activation of the enzyme, reaching maximal levels within 30 minutes. This activation appears to involve both insulin-receptor substrate (IRS)-1 (Niswender et al., 2001) and IRS-2 (Zhao et al., 2002b). Activation of phosphodiesterase 3B (PDE3B) by leptin, leading to reduced levels of hypothalamic cyclic adenosine monophosphate (cAMP), has been reported (Zhao et al., 2002b). The exact mechanisms by which $\mathrm{ObRb}$ activates PI3-K and the cAMP pathway are unknown.

Determination of the biological roles of the individual signaling pathways have begun. Primarily, elegant studies of mice lacking Y1138 of ObRb, the STAT3-binding site, show that this pathway is critical for appetite and body 


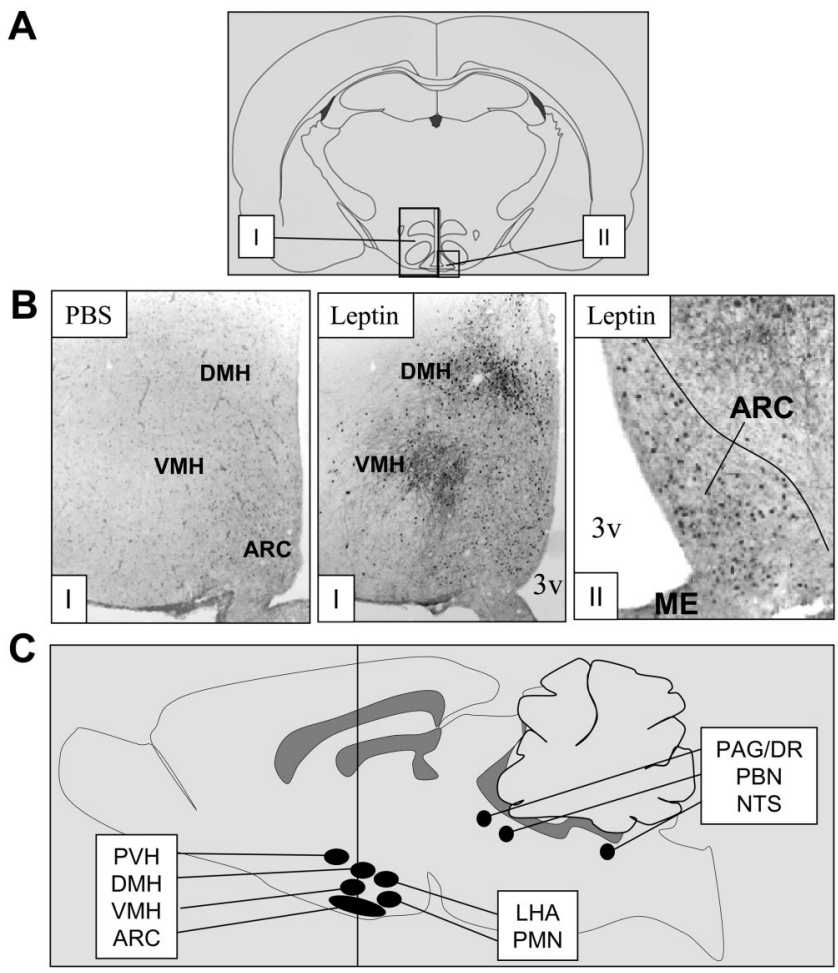

FIG. 1. Leptin-responsive regions in the rodent brain. (A) Schematic drawing of a coronal section of the rat brain. "I" and "II" depict hypothalamic nuclei that are highly leptin responsive. (B) The three microphotographs show immunohistochemistry (IHC) for phosphorylated signal transducer and activator of transcription (STAT) 3 of coronal brain sections containing region "I" and "II" from (A). Rats were given a single intraperitoneal (IP) injection of recombinant leptin $(1 \mathrm{mg} / \mathrm{kg})$ or vehicle (PBS) and sacrificed 20 minutes later (Muenzberg et al., 2003). The picture on the right shows a higher magnification (region "II" from (A)) where P-STAT3-positive cell nuclei in the arcuate nucleus of a leptin-treated animal can be identified. (C) Schematic drawing of a sagittal section of the rodent brain. Black areas depict approximate locations of the major leptin-responsive regions, as determined by IHC assays for STAT3 activation or c-Fos induction in brain sections from leptintreated animals (Elmquist et al., 1997; Elias et al., 2000; Hubschle et al., 2001; Hosoi et al., 2002; Muenzberg et al., 2003). Dark gray regions indicate ventricular systems. The vertical line indicates the approximate location of the coronal section shown in (A). Abbreviations: DMH, dorsomedial hypothalamic nucleus; VMH, ventromedial hypothalamic nucleus; ARC, arcuate nucleus; LHA, lateral hypothalamic area; PMN, premammilary nucleus; $\mathrm{PVH}$, paraventricular hypothalamic area; PAG, periaqueductal grey; DR, dorsal raphae; PBN, parabrachial nucleus; NTS, nucleus of the solitary tract; ME, median eminence; 3v, third ventricle. [(A) modified from Schwartz MW, Woods SC, Porte D Jr, Seeley RJ, Baskin DG 2000 Central nervous system control of food intake. Nature 404:661-671; (B) modified with permission from Muenzberg H, Huo L, Nillni EA, Hollenberg AN, Bjorbaek C 2003 Role of signal transducer and activator of transcription 3 in regulation of hypothalamic proopiomelanocortin gene expression by leptin. Endocrinology 144:2121-2131. Copyright 2003 The Endocrine Society.] 


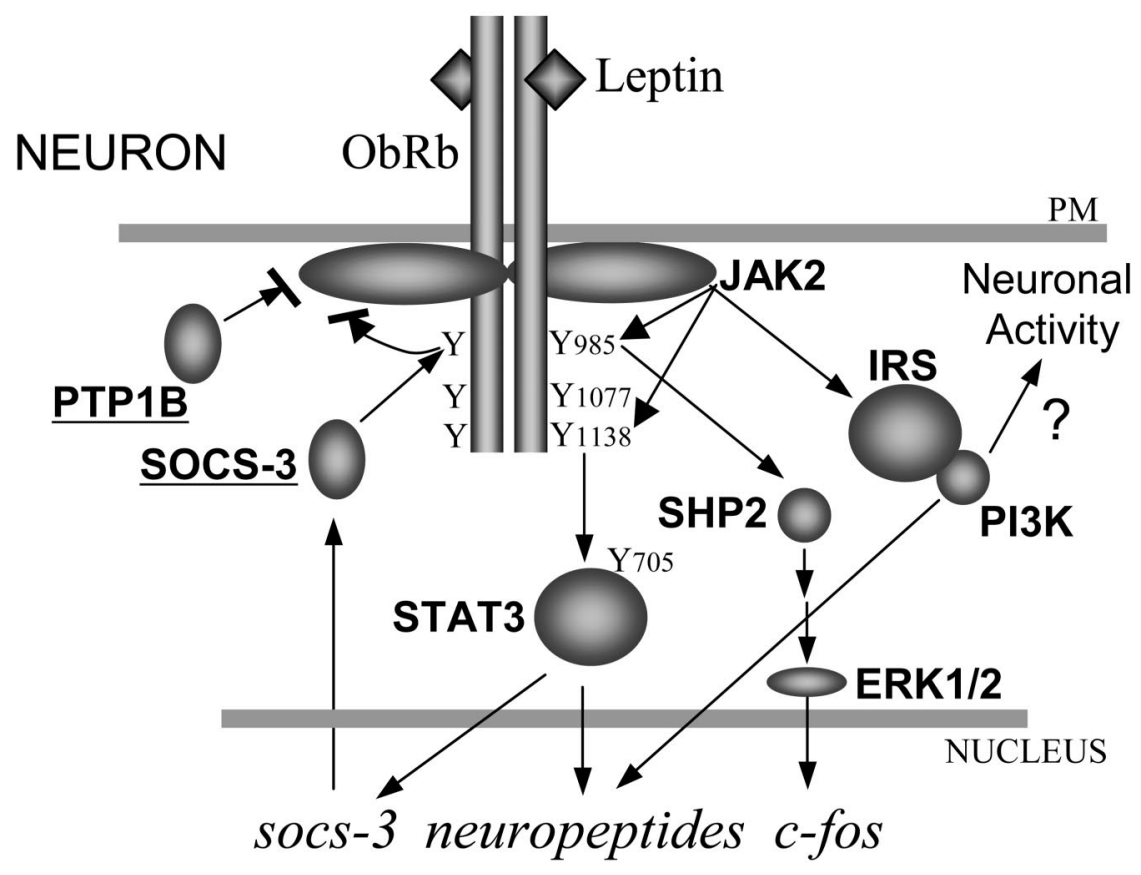

FIG. 2. Model for neuronal leptin receptor $(\mathrm{ObRb})$ signaling. Activation of ObRb by leptin leads to increased activity of intracellular janus activating kinase (JAK)2 kinases associated with membrane-proximal regions of the receptor. JAK2 phosphorylates a number of cellular substrates, including Y985 and Y1138 of ObRb and Y705 of STAT3, after binding to pY1138. SH-2-domainphosphotyrosine phosphatase (SHP-2) is important for activation of the extracellular signal-regulated kinase (ERK) pathway. STAT3, phosphoinositol-3 kinase (PI3-K), and ERK play roles in regulation of gene transcription. Suppressor of cytokine signaling (SOCS)-3 expression is regulated by the STAT3 pathway and, like protein tyrosine phosphatase (PTP)1B, is a negative regulator of $\mathrm{ObRb}$ signaling (indicated by underlining). PI3-K also may be involved in regulation of rapid nongenomic events affecting neuronal activity and neuropeptide release. PM, plasma membrane; IRS, insulin receptor substrate. [Modified from Bjorbaek C, Hollenberg AN 2002 Leptin and melanocortin signaling in the hypothalamus. Vitam Horm 65:288.]

weight regulation by leptin (Bates et al., 2003). In addition, indirect evidence from further analyses of these mice indicates that Y986 — and thus possibly the MAPK pathway - may play a positive role in regulation of linear growth and reproductive function by leptin. Intracerebroventricular (ICV) injection of inhibitors of PI3-K, Wortmanin or LY294002 (Niswender et al., 2001; Rahmouni et al., 2003), or of cilostamide (Zhao et al., 2002b), an inhibitor of PDE3, reverses the effect of leptin to reduce food intake, pointing to key roles of these pathways in leptin action to regulate appetite. A role for PI3-K to mediate leptin-induced stimulation of sympathetic outflow also has been reported (Rahmouni et al., 
2003). Finally, recent studies in our laboratory indicate that the AMP kinase pathway is involved in leptin's effect on food intake (Y. Minokoshi and B.B. Kahn, unpublished data).

Leptin also has rapid effects that lead to regulation of neuronal firing rates (Glaum et al., 1996; Powis et al., 1998; Cowley et al., 2001; Schwartz and Moran, 2002), where some cells are found to be activated while others are inhibited (Elias et al., 1998; Cowley et al., 2001). The underlying mechanism for this divergent signaling capacity of ObRb is not well understood, although activation of adenosine triphosphate (ATP)-sensitive potassium $\left(\mathrm{K}^{+}\right)$channels may play a role in inhibition (hyperpolarization) of neurons in the $\mathrm{VMH}$ (Spanswick et al., 1997). Some evidence also indicates that activation of IRS-associated PI3-K activity is involved in this process (Spanswick et al., 2000), a mechanism similar to that suggested for leptin to influence polarization of pancreatic $\beta$ cells (Harvey et al., 2000). However, leptin's effect to reduce food intake is not altered in mice lacking Kir6. $2 \mathrm{~K}^{+}$-ATP channels (Miki et al., 2001), which are expressed in $\beta$ cells and brain. Thus, the role of these $\mathrm{K}^{+}$-ATP channels in mediating leptin's anorexigenic effects is unclear. The rapid, nongenomic actions of leptin are likely to be critical for regulating immediate release of hypothalamic neuropeptides and neurotransmitters from nerve terminals (Figure 2).

\section{NEGATIVE REGULATORS OF LEPTIN SIGNALING}

A novel cytokine-inducible gene was reported in 1995 (Yoshimura et al., 1995) and later found to belong to a family of related genes. The protein products of these genes function as negative regulators of a wide variety of cytokine signaling systems, including those of IL-6, LIF, erythropoietin, and growth hormone (GH) (Endo et al., 1997; Naka et al., 1997; Starr et al., 1997). The four identified proteins were named cytokine-inducible sequence (CIS) and suppressors of cytokine signaling (SOCS)-1, -2 , and -3 . We speculated that since leptin has a tertiary structure that strongly resembles that of cytokines and since the leptin receptor belongs to the cytokine receptor superfamily, it was likely that leptin also would regulate gene expression of members of the newly identified gene family. Indeed, by injecting $o b / o b$ mice with a bolus of recombinant leptin, followed by quantitative reverse transcription-polymerase chain reaction (RTPCR) analysis of mRNA isolated from hypothalami 2 hours after administration, we found that SOCS-3 mRNA levels - but not CIS, SOCS-1, or SOCS-2 mRNA - were increased by leptin (Bjorbaek et al., 1998a). This did not occur in $d b / d b$ mice. Furthermore, in situ hybridization for SOCS-3 mRNA in the rat and mouse brains showed that leptin induced socs-3 expression in nuclei of the hypothalamus that were known to express the long form of the leptin receptor (Elmquist et al., 1998b). Moreover, we demonstrated that forced expression of 
SOCS-3 in transfected cells ablated leptin receptor tyrosine phosphorylation and downstream signaling, altogether showing that SOCS-3 is a leptin-inducible inhibitor of leptin signaling. Subsequent studies in our lab have demonstrated that SOCS-1 potently inhibits ObRb signaling in transfected cells (C. Bjorbaek and J.S. Flier, unpublished results), despite lack of evidence that leptin can induce SOCS-1 expression (Bjorbaek et al., 1998a,1999). This finding may be relevant for development of leptin resistance in obesity, if other cytokines induce SOCS-1 in leptin-responsive cells. Studies show that fasting of rats results in lower SOCS-3 mRNA levels in the ARC and DMH, as compared to fed animals, indicating that the fall of endogenous leptin during fasting regulates hypothalamic socs-3 expression (Baskin et al., 2000). Since functional STAT3 DNA binding elements are present in the socs-3 promoter (Auernhammer et al., 1999), and since lack of the STAT3 binding site on ObRb prevents induction of SOCS-3 mRNA by leptin (Banks et al., 2000), we conclude that leptin stimulates socs-3 transcription via the STAT3 pathway. Subsequent studies show that SOCS-3, via its SH-2 domain, binds to $\mathrm{Y} 985$ of $\mathrm{ObRb}$ and that this residue is required for maximal inhibition of signaling (Bjorbaek et al., 2000b). However, evidence also suggests that SOCS-3 acts via binding directly to JAK2 (Bjorbaek et al., 1999). SOCS-3 thus was the first identified negative regulator of leptin signaling.

Based on this evidence, we hypothesized that overreactivity of the SOCS pathway is a potential causal mechanism for leptin-resistant obesity. Consistent with this, in situ hybridization analyses showed that SOCS-3 mRNA levels were strongly elevated in the hypothalamus of $A^{y} / a$ mice, a genetic model of leptinresistant murine obesity (Bjorbaek et al., 1998a) and is increased in aged rats (Peralta et al., 2002), a state also associated with hyperleptinemia and leptin resistance (Scarpace et al., 2000). socs-1 gene expression is elevated in dietinduced obese (DIO) mice (Plut et al., 2003). However, somewhat disappointing to us, PCR analysis of SOCS-3 mRNA in whole hypothalamic tissue of DIO mice has not shown that this transcript is substantially increased in this model of obesity (El-Haschimi et al., 2000; Peiser et al., 2000; Plut et al., 2003). The finding of elevated SOCS-1 mRNA in DIO is intriguing and implies that factors other than leptin induce SOCS-1 expression in leptin-responsive neurons, leading to SOCS-1-induced leptin resistance in those cells. This mechanism could play a role in the development of obesity. Further quantitative anatomical studies of hypothalamic SOCS-1 and -3 protein levels in various obesity models are needed. Possibly, the SOCS pathways could be targets for development of anti-obesity drugs.

We and others have demonstrated that the protein tyrosine phosphatase 1B (PTP1B) is a physiological insulin receptor phosphatase and thus an important negative regulator of insulin signaling in vivo (Elchebly et al., 1999; Klaman et al., 2000). The fact that mice lacking PTP1B are resistant to developing DIO and are not hyperphagic, despite having low serum leptin levels, raised the possibility 
that PTP1B might be a negative regulator of leptin signaling. To test this hypothesis, we first examined leptin receptor signaling in mammalian cell lines transiently expressing ObRb with or without PTP1B. Leptin-induced JAK2 and STAT3 tyrosine phosphorylation was reduced dramatically in cells overexpressing PTP1B (Zabolotny et al., 2002). In vitro experiments suggested that PTP1B directly inhibits JAK2 kinase. Through in situ hybridization, we localized PTP1B mRNA to the hypothalamus, including the ARC nucleus. Furthermore, STAT3 phosphorylation in the hypothalamus was increased in leptin-treated mice lacking PTP1B (PTP1B $\left.{ }^{-/-}\right)$, consistent with PTP1B interacting with leptin-dependent signaling pathways in leptin-responsive brain nuclei (Zabolotny et al., 2002). We conclude that PTP1B is an intracellular inhibitor of central leptin receptor signaling and that the enzyme likely acts by directly dephosphorylating - and thus inhibiting - JAK2 activity. In parallel to these studies, Cheng and coworkers reported very similar findings (Cheng et al., 2002).

To test whether increased leptin signaling in the hypothalamus of leptintreated PTP1B ${ }^{-1-}$ mice resulted in hypersensitivity to the physiological actions of leptin to reduce body weight, $\mathrm{PTP}_{1 \mathrm{~B}}{ }^{-1-}, \mathrm{PTP}^{\mathrm{B}} \mathrm{B}^{+-}$, and wild-type (WT) mice were injected for 3 consecutive days with either leptin (three different doses) or vehicle. We found that WT mice lost weight only when given the highest dose of leptin. In contrast, $\mathrm{PTP}_{\mathrm{B}} \mathrm{B}^{-1-}$ mice responded to all doses and $\mathrm{PTP}_{1 \mathrm{~B}}{ }^{+/-}$mice exhibited intermediate leptin sensitivity. Combined with the results from earlier studies (Elchebly et al., 1999; Klaman et al., 2000), we conclude that PTP1B deficiency in mice results in increased sensitivity to insulin and leptin and resistance to DIO. These effects of PTP1B likely occur via central and peripheral actions of the protein. Thus, PTP1B is an attractive therapeutic target for treating human obesity and insulin-resistant diabetes.

\section{ROLE OF NEUROPEPTIDES IN LEPTIN ACTION}

In the ARC of the hypothalamus, different leptin-responsive neuronal populations can be distinguished (Elias et al., 1998; Korner et al., 1999). POMC neurons, producing the anorectic peptide alpha melanocyte-stimulating hormone ( $\alpha$-MSH) acting via the melanocortin 3/4 receptors (MC3/4-R), are believed to be key mediators of leptin action (Schwartz et al., 2000). Cocaine and amphetamine-regulated transcript (CART) is another potent inhibitor of feeding. Cells expressing this peptide overlap with POMC neurons (Elias et al., 1998; Kristensen et al., 1998). A separate population of cells in the ARC coexpresses two orexigenic peptides, the melanocortin receptor antagonist agouti-related protein (AgRP) and neuropeptide Y (NPY) (Ollmann et al., 1997; Elias et al., 1998; Bagnol et al., 1999; Baskin et al., 1999b; S.C. Chen et al., 1999; Ebihara et al., 1999). High proportions of the POMC/CART and NPY/AgRP cells express $\mathrm{ObRb}$ and thus are direct targets of circulating leptin (Hakansson et al., 1996; 
Mercer et al., 1996a; Cheung et al., 1997; Elmquist et al., 1998a; Hahn et al., 1998; Baskin et al., 1999b).

The importance of these neuropeptide systems in the ARC for leptin action is supported by findings that mice lacking functional leptin or leptin receptors are morbidly obese and have significantly reduced pomc mRNA levels in the hypothalamus, while AgRP and NPY mRNAs are strongly increased (Thornton et al., 1997; Hahn et al., 1998; Mizuno et al., 1998). In addition, fasting of normal mice and rats for 2-3 days leads to a fall in circulating leptin concentrations that is accompanied by a reduction of pomc mRNA and increases in hypothalamic NPY and AgRP that can be prevented by administration of recombinant leptin during the fasting period (Ahima et al., 1996; Schwartz et al., 1996,1997; Mizuno et al., 1998). The molecular basis for stimulation of pomc gene expression likely involves STAT3 activation (Muenzberg et al., 2003), while the PI3K pathway may play a specific role in repression of NPY and AgRP expression by leptin (Morrision et al., 2003). Recent studies show that POMC cells respond very rapidly to leptin by increasing axonal firing rates and decreasing membrane potentials (Cowley et al., 2001), leading to release of neurotransmitters and neuropeptides, including $\alpha$-MSH (M. Kim et al., 2000; Watanobe and Habu, 2002). In contrast, leptin hyperpolarizes NPY/AgRP neurons, presumably inhibiting release of peptides and neurotransmitters (Cowley et al., 2001,2003), as supported by release measurements in hypothalamic explants ( $\mathrm{Li}$ et al., 2000). Thus, POMC/CART neurons are activated and NPY/AgRP cells are inhibited by leptin, events that are directly associated with activation of c-Fos in POMC/CART but not in NPY/AgRP neurons (Elias et al., 1999). The mechanism by which ObRb has opposite signaling effects in different cells is intriguing.

It is difficult to reconcile recent findings that genetic ablation of NPY and AgRP in mice does not induce a lean phenotype (Qian et al., 2002). However, these studies were carried out on a mixed genetic background and, when studied on a pure C57B1/6 genetic background, NPY -/- mice do exhibit a defect in refeeding after a fast, consistent with a deficiency of orexigenic factors. Surprisingly, however, when given food ad libitum, the NPY -/- mice become slightly overweight and have increased adiposity, compared to control littermates. This demonstrates that genetic background must be taken into account when studying the biology of NPY (Segal-Lieberman et al., 2003). Further studies are required to understand how NPY $-/-$ mice develop obesity. In contrast, powerful pharmacological and genetic evidence in rodents clearly demonstrates that the melanocortin system plays a pivotal role in regulation of body weight by leptin (Fan et al., 1997; Seeley et al., 1997; Brown et al., 1998; Murphy et al., 1998; Marks and Cone, 2001). Moreover, mutations in the pomc gene (Krude et al., 1998; Yaswen et al., 1999) and in the gene encoding the MC4-R lead to severe 
obesity in rodents and humans (Huszar et al., 1997; Vaisse et al., 1998; Yeo et al., 1998).

Compelling data show that leptin can regulate the neuroendocrine thyroid axis in rodents and humans. Thyroid hormone levels fall dramatically during short-term starvation of rodents. This mechanism is partly responsible for the conservation of energy by reducing metabolism (Blake et al., 1991). The fall in thyroid hormones is associated with a reduction of hypothalamic thyrotropinreleasing hormone (TRH) mRNA expression that can be reversed by leptin treatment (Ahima et al., 1996; Legradi et al., 1997). In addition, the fall of thyrotropin-stimulating hormone (TSH) serum levels during 72 hours of fasting in humans can be blunted significantly by administering recombinant leptin (Chan et al., 2003).

Results from rodents suggest that the effect of leptin on the thyroid axis involves both direct actions of leptin on leptin receptors expressed on the hypophysiotrophic TRH neurons located in the PVH and indirect signals from neurons that project to those TRH neurons. Consistent with direct regulation are data showing that leptin can stimulate trh gene expression via a STAT3 response element located in the trh promoter in isolated cells (Harris et al., 2001) and induce STAT3 phosphorylation in TRH neurons in the PVH of leptin-treated rats (Muenzberg et al., 2003; C. Bjorbaek, unpublished data). Furthermore, leptin rapidly regulates polarization of neurons in isolated brain slices of the PVH (Powis et al., 1998) and can stimulate TRH peptide release from dispersed hypothalamic cultures and hypothalamic tissue ex vivo (M. Kim et al., 2000; Nillni et al., 2000). Other data support indirect regulation of TRH neurons via synaptic input from leptin-responsive POMC and NPY/AgRP neurons located in the ARC (Legradi et al., 1998; Fekete et al., 2000). Further studies will determine the relative physiological importance of these pathways that influence the hypophysiotrophic TRH neurons.

\section{Peripheral Leptin Receptor Signaling}

\section{A. LEPTIN RECEPTOR EXPRESSION IN THE PERIPHERY}

While few studies have convincingly demonstrated protein expression of leptin receptors in any tissue, high mRNA levels of ObRa are found in lungs, kidneys, and lymph nodes, with lower levels in heart, liver, skeletal muscle, spleen, white adipose tissue (WAT), adrenals, and testes (Tartaglia et al., 1995; Lee et al., 1996; Fei et al., 1997; Ghilardi and Skoda, 1997; Hoggard et al., 1997). While some signaling capacities of ObRa have been shown in cell systems (Bjorbaek et al., 1997; Murakami et al., 1997), the function of ObRa in the periphery remains largely unknown. 
Messenger RNA of the long-form receptor $\mathrm{ObRb}$ can be detected in several peripheral tissues, although to a more-limited degree and at much lower levels compared to ObRa. By applying Northern blotting, RT-PCR, or RNase-protection-assays, ObRb mRNA has been measured in lungs, kidneys, adrenals, and lymph nodes and at lower and variable levels in liver, brown adipose tissue (BAT), WAT, and skeletal muscle (Ghilardi et al., 1996; Hoggard et al., 1997; Kielar et al., 1998; P. Chen et al., 1999). In tissues where both receptor isoforms can be detected, ObRb mRNA accounts for under 5-10\% of total leptin receptor expression (Ghilardi and Skoda, 1997; Lollmann et al., 1997). ObRb proteins have not been demonstrated in any of the mentioned peripheral cells or tissues. One cannot, however, exclude a role of leptin signaling via ObRb in these tissues, since our experience shows that $\mathrm{ObRb}$ detection is difficult, even in transfected cells, mainly due to low expression levels of the ObRb protein (Bjorbaek et al., 1997; DaSilva et al., 1998; Uotani et al., 1999). Despite being poorly expressed, we did observe leptin-dependent signaling in transfected cells, consistent with studies showing that a very limited number of erythropoietin receptors $(<100-$ $250 /$ cell) is sufficient to activate biologically relevant signal transduction (Masuda et al., 1993). Finally, as will be described, rapid leptin-dependent events can be detected in vivo, in explants of peripheral tissues, and in cell lines derived thereof, thus supporting the presence of functional ObRb receptors at these sites.

\section{B. LEPTIN ACTION IN PERIPHERAL TISSUES}

When studying signaling by leptin directly in the periphery in vivo, effects that could be mediated via the CNS must be distinguished. To do this, one can investigate leptin-dependent action in cell lines derived from peripheral tissues or, even better, in primary tissues or cells, ex vivo. Numerous studies have utilized the first approach and reported effects on intracellular signaling and metabolism in cell lines derived from blood cells (Cioffi et al., 1996; O'Rourke et al., 2001), pancreatic $\beta$ cells (Ahren and Havel, 1999; Morton et al., 1999; Briscoe et al., 2001; Okuya et al., 2001), pituitary cells (Tsumanuma et al., 2000), kidney (Takahashi et al., 1996), and insulin-sensitive cells like hepatocytes (Szanto and Kahn, 2000; Briscoe et al., 2001; Zhao et al., 2002a), muscle cells (Berti et al., 1997; Berti and Gammeltoft, 1999; Kellerer et al., 1997; Takahashi et al., 1997), and adipocytes (Bai et al., 1996; Y. Kim et al., 2000). Although leptin receptor-like signaling (activation of STAT3 and/or MAPK pathways) and ObRb mRNA (by RT-PCR) is reported in many of these cell lines, in only one study in a macrophage-derived cell line is the presence of functional ObRb proteins convincingly demonstrated (O'Rourke et al., 2001). This suggests either very low expression levels in the other cell types or activation of unknown leptin-sensitive receptor systems. The latter seems unlikely, since leptin-dependent signaling via receptors other than ObR has not been reported. 
The degree of understanding of the biological function of leptin action in these cell types varies, depending on the tissue. Strong data support a role for leptin in immune cells. Ex vivo studies of isolated T lymphocytes from mice and humans suggest that leptin has anti-immunosuppressive effects and promotes cellular survival (Lord et al., 1998; Howard et al., 1999; Martin-Romero et al., 2000; Sanchez-Margalet and Martin-Romero, 2001). This provides a mechanism that may account for modulation of the change in immune function seen during starvation. Furthermore, a number of studies of isolated pancreatic islets from rodents strongly indicate that leptin can inhibit insulin secretion (Emilsson et al., 1997; Fehmann et al., 1997; Ishida et al., 1997; Kieffer et al., 1997; Kulkarni et al., 1997; Roduit and Thorens, 1997; Ookuma et al., 1998; Poitout et al., 1998; Lupi et al., 1999; Morton et al., 1999; Seufert et al., 1999; Islam et al., 2000), although the opposite effect or no effect also has been reported (Pallett et al., 1997; Shimizu et al., 1997; Tanizawa et al., 1997; Kawai et al., 2001). Further studies are needed to resolve these discrepancies. In favor of a direct effect on pituitary cells are data showing leptin-induced release of LH and FSH from isolated pituitary explants from rats (Yu et al., 1997). This is consistent with the known link between leptin and reproductive function (Ahima et al., 1996,1997), although a significant part of this regulation is likely of hypothalamic origin. While leptin can stimulate sympathetic nerve activity to the kidneys via the CNS (Haynes et al., 1999), direct actions of leptin to influence kidney function have not been described. One can, however, envision a potential role for short- or long-form leptin receptors to facilitate renal clearance of leptin from the circulation. We will discuss in more detail experiments from our own laboratory aimed at increasing the understanding of leptin-dependent signaling in adipose tissue, liver, and skeletal muscle, the classic insulin-sensitive tissues.

To carefully investigate leptin receptor signaling directly in insulin-sensitive tissues in vivo, rats were injected intravenously (IV) with a bolus of recombinant leptin (and/or insulin) and sacrificed 3 minutes later (Y. Kim et al., 2000). Activation of STAT1, STAT3, MAPK, PI3-K, and Akt was examined in muscle, WAT, and liver. In adipose tissue, we found that leptin had profound effects to increase STAT1 and STAT3 phosphorylation and, to a lesser degree, activate MAPK and PI3-K. Under the same conditions, leptin did not affect signaling in $d b / d b$ mice, which lack ObRb. Akt was not activated by leptin in any tissue and activation of signaling pathways in liver was less robust, as compared to fat tissue. Although we did not find evidence of very rapid effects in muscle on any of the measured endpoints, others have reported activation of STAT3 and Akt at later time points (Maroni et al., 2003). A critical role for leptin signaling directly in liver tissue has been ruled out following demonstration that conditional $\mathrm{KO}$ of hepatic ObR does not lead to a discernible phenotype in terms of glucose homeostasis or other parameters (Cohen et al., 2001). Insulin induced strong activation of PI3K, Akt, and MAPK in all tissues, while STAT1 and STAT3 were 
activated only in adipose tissue. Since signaling was activated just 3 minutes after injection, the observed effects were unlikely to be mediated indirectly by other humoral factors. Indeed, MAPK was rapidly induced in explants of adipose tissue, demonstrating that this was a direct effect of leptin (Y. Kim et al., 2000). Detection of ObRb mRNA in human and rodent WAT further supports the notion of direct actions of leptin on fat cells (Siegrist-Kaiser et al., 1997; Kielar et al., 1998; Kutoh et al., 1998). However, since this was measured by RT-PCR, final conclusions about the presence of functionally relevant ObRbs on fat cells are premature.

These signaling studies provide ample basis to speculate about the biological roles of leptin in fat cells and in possible cross-talk with insulin-signaling pathways. While leptin does not appear to directly affect glucose uptake in mouse or rat adipocytes (Zierath et al., 1998), studies have shown robust and sensitive leptin-dependent induction of lipolysis in isolated fat pads or isolated adipocytes from rats (Siegrist-Kaiser et al., 1997; Wang et al., 1999; Rodriguez et al., 2003) and mice (Fruhbeck et al., 1997; Kawaji et al., 2001). Consistent with this, leptin antagonizes the effects of insulin to inhibit lipolysis (Muller et al., 1997). Furthermore, no increase in triglyceride breakdown could be measured in fat cells derived from Zucker $f a / f a$ rats or $d b / d b$ mice, both lacking functional leptin receptors (Fruhbeck et al., 1997; Siegrist-Kaiser et al., 1997; Wang et al., 1999). Combined, these studies suggest opposing effects of leptin on insulin action in WAT, although one study reported that leptin had no effect on lipolysis in isolated adipocytes from humans (Elimam et al., 2002), possibly indicating species differences. Based on rodent studies that suggested opposite effects of leptin and insulin on lipolysis, we speculated that since leptin and insulin activate STAT3 to a similar degree (Y. Kim et al., 2000), this signaling pathway alone is unlikely to play a role in the lipolytic effect of leptin. On the other hand, one can envision that the STAT3 pathway, which leads to induction of SOCS-3 expression, may play a role in the inhibitory effect of leptin on insulin action, since SOCS-3-mediated downregulation of IRS signaling has been reported (Emanuelli et al., 2001; Rui et al., 2002). As GH also stimulates SOCS-3 expression, a similar mechanism has been proposed to explain the antagonistic effect of $\mathrm{GH}$ on insulin action in adipocytes (Ridderstrale et al., 2003).

\section{ROLE OF AMP-ACTIVATED PROTEIN KINASE IN LEPTIN SIGNALING IN SKELETAL MUSCLE}

Although leptin stimulates glucose transport in muscle indirectly through the hypothalamus and the sympathetic nervous system (SNS) (Kamohara et al., 1997), evidence does not support rapid, leptin-dependent activation of STAT3, MAPK, or PI3-K (Y. Kim et al., 2000) or glucose uptake (Muoio et al., 1997; Zierath et al., 1998) directly in skeletal muscle. However, our recent results 
provide insight into other metabolic actions of leptin in muscle. We discovered activation of a signaling pathway that has not previously been ascribed to the leptin receptor, namely, regulation of the AMP-activated protein kinase (AMPK).

AMPK is a serine/theronine kinase that is conserved from yeast to humans and is activated by an increased intracellular ratio of AMP to ATP and by upstream kinases. Considerable research has focused on the role of this enzyme in regulation of substrate metabolism. AMPK has been proposed to serve as a master fuel gauge in mammalian cells (Hardie and Carling, 1997). AMPK phosphorylates acetyl-coA carboxylase (ACC), leading to inhibition of ACC and stimulation of fatty acid oxidation in mitochondria (Winder and Hardie, 1999; Hardie and Pan, 2003). Leptin treatment of rodents reduces intracellular lipid content in muscle at doses that evidently do not affect body weight (Unger et al., 1999) and leptin can increase oxidation of fatty acids in muscle tissue ex vivo (Muoio et al., 1997). Although most leptin actions are mediated via the CNS, we speculated that at least part of the observed effects in skeletal muscle in vivo occur through direct activation of AMPK.

To test this hypothesis, we injected leptin IV into mice and measured AMPK activity in soleus muscle 15 minutes and up to 6 hours after administration. Leptin produced a biphasic response, with a 2 -fold rise at 15 minutes, a return to baseline by 60 minutes, and a second 2-fold elevation by 6 hours (Minokoshi et $a l ., 2002)$. Of two known isoforms of the catalytic subunit of AMPK, $\alpha 1$ and $\alpha 2$, we detected activation of only $\alpha 2$ AMPK by leptin. To determine whether the effect of leptin was mediated via actions in the hypothalamus and SNS, several experiments were undertaken. First, injection of small doses of leptin directly into the hypothalamus resulted in a 3-fold activation of AMPK in soleus muscle at 60 minutes that remained elevated at 6 hours. This demonstrates that central action of leptin can regulate signaling events in muscle tissue and suggests that the regulation of AMPK seen after IV injection is explained partly by central actions of leptin. To directly test the relative role of central vs. direct effects, we measured AMPK activity in mice with surgical denervation of one hindlimb. Combined denervation of the femoral, sciatic, and obturator nerves blocked the ability of leptin administered either directly into the hypothalamus or IV (6 hours after administration) to stimulate $\alpha 2$ AMPK in muscle. In contrast, activation at 15 minutes was intact after IV leptin administration, altogether indicating that rapid activation involves a direct event and that slower activation of AMPK in muscle requires activation of the autonomic nervous system. To more-conclusively support the direct action, we incubated soleus muscle ex vivo with and without leptin and found a robust, leptin-dependent 2- to 3-fold increase in $\alpha 2$ AMPK activity. The biological effects of this pathway involve upregulation of fatty acid oxidation. Leptin phosphorylates ACC, resulting in an expected decrease in ACC enzymatic activity and increased fatty acid oxidation (Figure 3). 


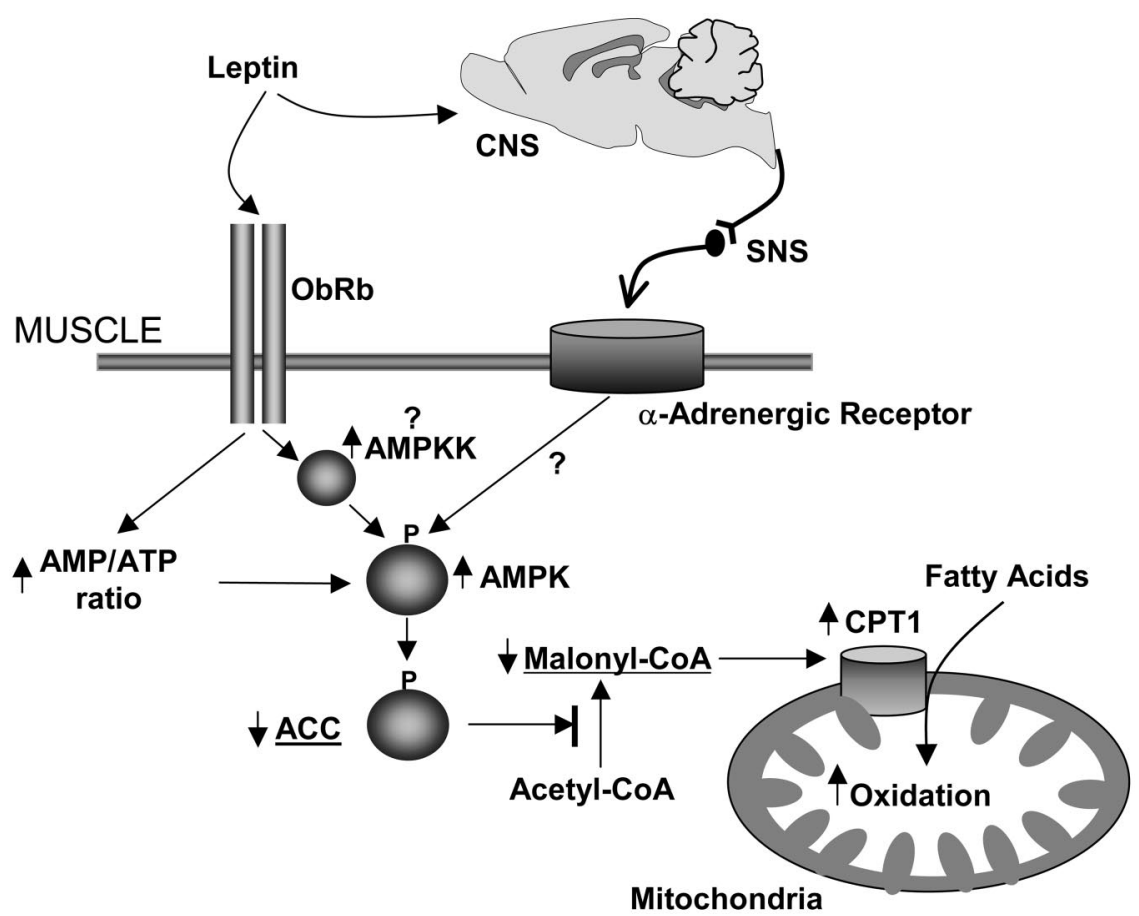

FIG. 3. Model for regulation of adenosine monophosphate-activated protein kinase (AMPK) and fatty acid oxidation by leptin in skeletal muscle. Leptin activates AMPK via two distinct mechanisms. One is rapid and occurs directly through leptin receptors expressed on muscle cells. The other occurs with slower kinetics and is mediated via actions in the central nervous system (CNS), leading to stimulation of the sympathetic nervous system (SNS) and activation of G-coupled $\alpha$-adrenergic receptors expressed on muscle cells. Activation of muscle ObRb also increases AMP content, which may be the mechanism for the direct effect of leptin to activate AMPK. AMPK phosphorylates acetyl-CoA carboxylase (ACC), leading to inhibition of its activity and thus to reduced formation of malonyl-CoA. This, in turn, disinhibits the activity of carnitine palmitoyltransferase 1 (CPT-1), a required step for translocation of fatty acids into mitochondria (Minokoshi and Kahn, 2003). Underlining indicates a decrease in cellular contents (malonyl-CoA) or in enzyme activities (ACC). ATP, adenosine triphosphate. [Modified from Minokoshi Y, Kahn BB 2003 Role of AMP-activated protein kinase in leptin-induced fatty acid oxidation in muscle. Biochem Soc Trans 31:196-201.]

The mechanism for AMPK activation in muscle at 15 minutes after IV leptin may result from an increase in AMP content in muscle. However, no changes in AMP amounts were seen 6 hours after IV leptin, indicating that AMPK activation through the hypothalamic SNS axis involves upstream AMPK kinase (Hardie and Pan, 2003). Furthermore, activation of AMPK is necessary for leptin's effect on ACC activity and presumably for its effects on fatty acid oxidation (Mino- 
koshi et al., 2002). Other studies applying long-term leptin treatment of rats (i.e., 2 weeks) showed an increase of both $\alpha 2$ AMPK phosphorylation and of AMPK protein expression, compared to pair-fed control animals (Steinberg et al., 2002). However, these studies could not conclude whether the effects were direct or indirect or both. We went on to show that the mechanism by which leptin indirectly activates AMPK in muscle involves $\alpha$-adrenergic receptors in muscle tissue (Minokoshi et al., 2002). These studies clearly suggest that leptin can directly stimulate fatty acid oxidation via AMPK and that this represents a novel pathway mediating metabolic actions of leptin in the periphery. This pathway may play a role in the fat-melting activity of leptin in peripheral tissues and also in protecting nonadipocytes from lipotoxicity by preventing upregulation of lipogenesis (Unger et al., 1999).

\section{Conclusion and Perspectives}

Major advances have been made in understanding leptin action. A complex network of interacting signaling pathways appears to regulate food intake, fuel balance, and body weight. Compelling evidence exists that, in addition to signaling in the CNS, leptin exerts its metabolic effects by acting directly on peripheral tissues. The relative importance of this signaling in the periphery for regulating adiposity and glucose homeostasis remains to be determined. Other important challenges include determining 1) how different pathways downstream of leptin (STAT3, PI3K, MAPK, AMPK) are integrated in the regulation of body weight; 2) how leptin signaling integrates with insulin-signaling pathways in the CNS; 3) the molecular mechanisms for leptin resistance in obesity; and 4) whether insulin resistance occurs in the brain in states such as obesity and diabetes that are associated with insulin resistance in the periphery. Molecules identified over the last several years provide new potential drug targets for the prevention and treatment of obesity.

\section{ACKNOWLEDGMENTS}

This work was supported by grants from the National Institutes of Health (DK-60673 to C.B. and DK-60839, DK-56116, and DK-60839 to B.B.K.) and a grant from the American Diabetes Association (to B.B.K.). We thank Dr. Y. Minokoshi (Beth Israel Deaconess Medical Center) for outstanding work; Dr. H. Muenzberg (Beth Israel Deaconess Medical Center) for assistance with Figure 1; and Dr. M.G. Myers, Jr. (Joslin Diabetes Center, Boston) and Dr. J.K. Elmquist (Beth Israel Deaconess Medical Center, Boston) for helpful comments on the manuscript.

\section{REFERENCES}

Ahima RS, Prabakaran D, Mantzoros C, Qu D, Lowell B, Maratos-Flier E, Flier JS 1996 Role of leptin in the neuroendocrine response to fasting. Nature 382:250-252 
Ahima RS, Dushay J, Flier SN, Prabakaran D, Flier JS 1997 Leptin accelerates the onset of puberty in normal female mice. J Clin Invest 99:391-395

Ahren B, Havel PJ 1999 Leptin inhibits insulin secretion induced by cellular cAMP in a pancreatic B cell line (INS-1 cells) Am J Physiol 277:R959-R966

Auernhammer CJ, Bousquet C, Melmed S 1999 Autoregulation of pituitary corticotroph SOCS-3 expression: characterization of the murine SOCS-3 promoter. Proc Natl Acad Sci USA 96:6964-6969

Bagnol D, Lu XY, Kaelin CB, Day HE, Ollmann M, Gantz I, Akil H, Barsh GS, Watson SJ 1999 Anatomy of an endogenous antagonist: relationship between Agouti-related protein and proopiomelanocortin in brain. J Neurosci 19:RC26

Bai Y, Zhang S, Kim KS, Lee JK, Kim KH 1996 Obese gene expression alters the ability of 30A5 preadipocytes to respond to lipogenic hormones. J Biol Chem 271:13939-13942

Banks AS, Davis SM, Bates SH, Myers MG Jr 2000 Activation of downstream signals by the long form of the leptin receptor. J Biol Chem 275:14563-14572

Barr VA, Lane K, Taylor SI 1999 Subcellular localization and internalization of the four human leptin receptor isoforms J Biol Chem 274:21416-21424

Baskin DG, Breininger JF, Bonigut S, Miller MA 1999a Leptin binding in the arcuate nucleus is increased during fasting. Brain Res 828:154-158

Baskin DG, Breininger JF, Schwartz MW 1999b Leptin receptor mRNA identifies a subpopulation of neuropeptide Y neurons activated by fasting in rat hypothalamus. Diabetes 48:828-833

Baskin DG, Breininger JF, Schwartz MW 2000 SOCS-3 expression in leptin-sensitive neurons of the hypothalamus of fed and fasted rats. Regul Pept 92:9-15

Bates SH, Stearns WH, Dundon TA, Schubert M, Tso AW, Wang Y, Banks AS, Lavery HJ, Haq AK, Maratos-Flier E, Neel BG, Schwartz MW, Myers MG Jr 2003 STAT3 signalling is required for leptin regulation of energy balance but not reproduction. Nature 421:856-859

Berti L, Kellerer M, Capp E, Haring HU 1997 Leptin stimulates glucose transport and glycogen synthesis in $\mathrm{C} 2 \mathrm{C} 12$ myotubes: evidence for a P13-kinase mediated effect. Diabetologia 40:606-609

Berti L, Gammeltoft S 1999 Leptin stimulates glucose uptake in C2C12 muscle cells by activation of ERK2. Mol Cell Endocrinol 157:121-130

Bjorbak C, Lavery HJ, Bates SH, Olson RK, Davis SM, Flier JS, Myers MG Jr. 2000 SOCS3 mediates feedback inhibition of the leptin receptor via Tyr985. J Biol Chem 275:40649_ 40657

Bjorbaek C, Hollenberg AN 2002 Leptin and melanocortin signaling in the hypothalamus. Vitam Horm 65:288

Bjørbæk C, Uotani S, da Silva B, Flier JS 1997 Divergent signaling capacities of the long and short isoforms of the leptin receptor. J Biol Chem 272:32686-32695

Bjørbæk C, Elmquist JK, Frantz, JD, Shoelson SE, Flier JS 1998a Identification of SOCS-3 as a potential mediator of central leptin resistance. Mol Cell 1:619-625

Bjørbæk C, Elmquist JK, Michl P, Ahima RS, van Bueren A, McCall AL, Flier JS 1998b Expression of leptin receptor isoforms in rat brain microvessels. Endocrinology 139:34853491

Bjørbæk C, El-Haschimi K, Frantz JD, Flier JS 1999 The role of SOCS-3 in leptin signaling and leptin resistance. J Biol Chem 274:30059-30065

Bjørbæk C, Buchholz RM, Davis SM, Bates SH, Pierroz DD, Gu H, Neel BG, Myers MG Jr, Flier JS 2000 Divergent roles of SHP-2 in ERK activation by leptin receptors. J Biol Chem 276:4747-4755

Blake NG, Eckland DJ, Foster OJ, Lightman SL 1991 Inhibition of hypothalamic thyrotropinreleasing hormone messenger ribonucleic acid during food deprivation. Endocrinology 129:2714-2718 
Briscoe CP, Hanif S, Arch JR, Tadayyon M 2001 Fatty acids inhibit leptin signalling in BRIN-BD11 insulinoma cells. J Mol Endocrinol 26:145-154

Brown KS, Gentry RM, Rowland NE 1998 Central injection in rats of alpha-melanocytestimulating hormone analog: effects on food intake and brain Fos. Regul Pept 78:89-94

Campfield LA, Smith FJ, Guisez Y, Devos R, Burn P 1995 Recombinant mouse OB protein: evidence for peripheral signal linking adiposity and central neural networks. Science 269: 546-549

Chan JL, Heist K, DePaoli AM, Veldhuis JD, Mantzoros CS 2003 The role of falling leptin levels in the neuroendocrine and metabolic adaptation to short-term starvation in healthy men. J Clin Invest 111:1409-1421

Chen H, Chatlat O, Tartaglia LA, Woolf EA, Weng X, Ellis SJ, Lakey ND, Culpepper J, Moore KJ, Breitbart RE, Duyk GM, Tepper RI, Morgenstern JP 1996 Evidence that the diabetes gene encodes the leptin receptor: identification of a mutation in the leptin receptor gene in $\mathrm{db} / \mathrm{db}$ mice. Cell 84:491-495

Chen P, Li C, Haskell-Luevano C, Cone RD, Smith MS 1999 Altered expression of agouti-related protein and its colocalization with neuropeptide $\mathrm{Y}$ in the arcuate nucleus of the hypothalamus during lactation. Endocrinology 140:2645-2650

Chen SC, Kochan JP, Campfield LA, Burn P, Smeyne RJ 1999 Splice variants of the OB receptor gene are differentially expressed in brain and peripheral tissues of mice. J Recept Signal Transduct Res 19:245-266

Cheng A, Uetani N, Simoncic PD, Chaubey VP, Lee-Loy A, McGlade CJ, Kennedy BP, Tremblay ML 2002 Attenuation of leptin action and regulation of obesity by protein tyrosine phosphatase 1B. Dev Cell 2:497-503

Cheung CC, Clifton DK, Steiner RA 1997 Proopiomelanocortin neurons are direct targets for leptin in the hypothalamus. Endocrinology 138:4489-4492

Cioffi JA, Shafer AW, Zupancic TJ, Smith-Gbur J, Mikhail A, Platika D, Snodgrass HR 1996 Novel B219/OB receptor isoforms: possible role of leptin in hematopoiesis and reproduction. Nature Med 2:585-589

Clement K, Vaisse C, Lahlou N, Cabrol S, Pelloux V, Cassuto D, Gourmelen M, Dina C, Chambaz J, Lacorte JM, Basdevant A, Bougneres P, Lebouc Y, Froguel P, Guy-Grand B 1998 A mutation in the human leptin receptor gene causes obesity and pituitary dysfunction. Nature 392:398-401

Cohen P, Zhao C, Cai X, Montez JM, Rohani SC, Feinstein P, Mombaerts P, Friedman JM 2001 Selective deletion of leptin receptor in neurons leads to obesity. J Clin Invest 108:1113-1121

Corp ES, Conze DB, Smith F, Campfield LA 1998 Regional localization of specific [125I]leptin binding sites in rat forebrain. Brain Res 789:40-47

Cowley MA, Smart JL, Rubinstein M, Cerdan MG, Diano S, Horvath TL, Cone RD, Low MJ 2001 Leptin activates anorexigenic POMC neurons through a neural network in the arcuate nucleus. Nature 411:480-484

Cowley MA, Cone RD, Enriori P, Louiselle I, Williams SM, Evans AE 2003 Electrophysiological actions of peripheral hormones on melanocortin neurons. Ann NY Acad Sci 994:175-186

Da Silva BA, Bjorbaek C, Uotani S, Flier JS 1998 Functional properties of leptin receptor isoforms containing the gln $\rightarrow$ pro extracellular domain mutation of the fatty rat. Endocrinology 139:3681-3690

Ebihara K, Ogawa Y, Katsuura G, Numata Y, Masuzaki H, Satoh N, Tamaki M, Yoshioka T, Hayase M, Matsuoka N, Aizawa-Abe M, Yoshimasa Y, Nakao K 1999 Involvement of agouti-related protein, an endogenous antagonist of hypothalamic melanocortin receptor, in leptin action. Diabetes 48:2028-2033 
Elchebly M, Payette P, Michaliszyn E, Cromlish W, Collins S, Loy AL, Normandin D, Cheng A, Himms-Hagen J, Chan CC, Ramachandran C, Gresser MJ, Tremblay ML, Kennedy BP 1999 Increased insulin sensitivity and obesity resistance in mice lacking the protein tyrosine phosphatase-1B gene. Science 283:1544-1548

El-Haschimi K, Pierroz DD, Hileman SM, Bjorbaek C, Flier JS 2000 Two defects contribute to hypothalamic leptin resistance in mice with diet-induced obesity. J Clin Invest 105:18271832

Elias CF, Lee C, Kelly J, Aschkenasi C, Ahima RS, Couceyro PR, Kuhar MJ, Saper CB, Elmquist JK 1998 Leptin activates hypothalamic CART neurons projecting to the spinal cord. Neuron 21:1375-1385

Elias CF, Aschkenasi C, Lee C, Kelly J, Ahima RS, Bjorbaek C, Flier JS, Saper CB, and Elmquist JK 1999 Leptin differentially regulates NPY and POMC neurons projecting to the lateral hypothalamic area. Neuron 23:775-786

Elias CF, Kelly JF, Lee CE, Ahima RS, Drucker DJ, Saper CB, Elmquist JK 2000 Chemical characterization of leptin-activated neurons in the rat brain. J Comp Neurol 423:261-281

Elimam A, Kamel A, Marcus C 2002 In vitro effects of leptin on human adipocyte metabolism. Horm Res 58:88-93

Elmquist JK, Ahima RS, Maratos-Flier E, Flier JS, Saper CB 1997 Leptin activates neurons in ventrobasal hypothalamus and brainstem. Endocrinology 138:839-842

Elmquist JK, Maratos-Flier E, Saper CB, Flier JS 1998 Unraveling the central nervous system pathways underlying responses to leptin. Nature Neurosci 1:445-450

Elmquist JK, Bjørbæk C, Ahima RS, Flier JS, Saper CB 1998 Distributions of leptin receptor mRNA isoforms in the rat brain. J Comp Neurol 395:535-547

Emanuelli B, Peraldi P, Filloux C, Chavey C, Freidinger K, Hilton DJ, Hotamisligil GS, Van Obberghen E 2001 SOCS-3 inhibits insulin signaling and is up-regulated in response to tumor necrosis factor-alpha in the adipose tissue of obese mice. J Biol Chem 276:4794447949

Emilsson V, Liu YL, Cawthorne MA, Morton NM, Davenport M 1997 Expression of the functional leptin receptor mRNA in pancreatic islets and direct inhibitory action of leptin on insulin secretion. Diabetes 46:313-316

Endo TA, Masuhara M, Yokouchi M, Suzuki R, Sakamoto H, Mitsui K, Matsumoto A, Tanimura S, Ohtsubo M, Misawa H, Miyazaki T, Leonor N, Taniguchi T, Fujita T, Kanakura Y, Komiya S, Yoshimura A 1997 A new protein containing an SH2 domain that inhibits JAK kinases. Nature 387:921-924

Fan W, Boston BA, Kesterson RA, Hruby VJ, Cone RD 1997 Role of melanocortinergic neurons in feeding and the agouti obesity syndrome. Nature 385:165-168

Fehmann HC, Berghofer P, Brandhorst D, Brandhorst H, Hering B, Bretzel RG, Goke B 1997 Leptin inhibition of insulin secretion from isolated human islets. Acta Diabetol 34:249-252

Fei H, Okano HJ, Li C, Lee GH, Zhao C, Darnell R, Friedman JM 1997 Anatomic localization of alternatively spliced leptin receptors (Ob-R) in mouse brain and other tissues. Proc Natl Acad Sci USA 94:7001-7005

Fekete C, Legradi G, Mihaly E, Huang QH, Tatro JB, Rand WM, Emerson CH, Lechan RM 2000 alpha-Melanocyte-stimulating hormone is contained in nerve terminals innervating thyrotropin-releasing hormone-synthesizing neurons in the hypothalamic paraventricular nucleus and prevents fasting-induced suppression of prothyrotropin-releasing hormone gene expression. J Neurosci 20:1550-1558

Frederich RC, Hamann A, Anderson S, Lollmann B, Lowell BB, Flier JS 1995 Leptin levels reflect body lipid content in mice: evidence for diet-induced resistance to leptin action. Nature Med 1:1311-1314 
Friedman JM, Halaas JL 1998 Leptin and the regulation of body weight in mammals. Nature 395:763-770

Fruhbeck G, Aguado M, Martinez JA 1997 In vitro lipolytic effect of leptin on mouse adipocytes: evidence for a possible autocrine/paracrine role of leptin. Biochem Biophys Res Commun 240:590-594

Ghilardi N, Skoda RC 1997 The leptin receptor activates janus kinase 2 and signals for proliferation in a factor-dependent cell line. Mol Endocrinol 11:393-399

Ghilardi N, Ziegler S, Wiestner A, Stoffel R, Heim MH, Skoda RC 1996 Defective STAT signaling by the leptin receptor in diabetic mice. Proc Natl Acad Sci USA 93:6231-6235

Glaum SR, Hara M, Bindokas VP, Lee CC, Polonsky KS, Bell GI, Miller RJ 1996 Leptin, the obese gene product, rapidly modulates synaptic transmission in the hypothalamus. Mol Pharmacol 50:230-235

Guan XM, Hess JF, Yu H, Hey PJ, van der Ploeg LH 1997 Differential expression of mRNA for leptin receptor isoforms in the rat brain. Mol Cell Endocrinol 133:1-7

Hahn TM, Breininger JF, Baskin DG, Schwartz MW 1998 Coexpression of Agrp and NPY in fasting-activated hypothalamic neurons. Nature Neurosci 1:271-272

Hakansson ML, Hulting AL, Meister B 1996 Expression of leptin receptor mRNA in the hypothalamic arcuate nucleus - relationship with NPY neurons. Neuroreport 7:3087-3092

Halaas JL, Gajiwala KS, Maffei M, Cohen SL, Chait BT, Rabinowitz D, Lallone RL, Burley SK, Friedman JM 1995 Weight-reducing effects of the plasma protein encoded by the obese gene. Science 269:543-546

Hardie DG, Carling D 1997 The AMP-activated protein kinase — fuel gauge of the mammalian cell? Eur J Biochem 246:259-273

Hardie DG, Pan DA 2003 Regulation of fatty acid synthesis and oxidation by the AMP-activated protein kinase. Biochem Soc Trans 30:1064-1070

Harris M, Aschkenasi C, Elias CF, Chandrankunnel A, Nillni EA, Bjorbaek C, Elmquist JK, Flier JS, Hollenberg AN 2001 Transcriptional regulation of the thyrotropin-releasing hormone gene by leptin and melanocortin signaling. J Clin Invest 107:111-120

Harvey J, McKay NG, Walker KS, Van der Kaay J, Downes CP, Ashford ML 2000 Essential role of phosphoinositide 3-kinase in leptin-induced K(ATP) channel activation in the rat CRI-G1 insulinoma cell line. J Biol Chem 275:4660-4669

Haynes WG, Morgan DA, Djalali A, Sivitz WI, Mark AL 1999 Interactions between the melanocortin system and leptin in control of sympathetic nerve traffic. Hypertension 33:542_ 547

Hileman SM, Pierroz DD, Masuzaki H, Bjorbaek C, El-Haschimi K, Banks WA, Flier JS 2002 Characterizaton of short isoforms of the leptin receptor in rat cerebral microvessels and of brain uptake of leptin in mouse models of obesity. Endocrinology 143:775-783

Hileman SM, Tornoe J, Flier JS, Bjorbaek C 2000 Transcellular transport of leptin by the short leptin receptor isoform ObRa in Madin-Darby canine kidney cells. Endocrinology 141:19551961

Hoggard N, Mercer JG, Rayner DV, Moar K, Trayhurn P, Williams LM 1997 Localization of leptin receptor mRNA splice variants in murine peripheral tissues by RT-PCR and in situ hybridization. Biochem Biophys Res Commun 232:383-387

Hosoi T, Kawagishi T, Okuma Y, Tanaka J, Nomura Y 2002 Brain stem is a direct target for leptin's action in the central nervous system. Endocrinology 143:3498-3504

Howard JK, Lord GM, Matarese G, Vendetti S, Ghatei MA, Ritter MA, Lechler RI, Bloom SR 1999 Leptin protects mice from starvation-induced lymphoid atrophy and increases thymic cellularity in ob/ob mice. Clin Invest 104:1051-1059 
Hubschle T, Thom E, Watson A, Roth J, Klaus S, Meyerhof W 2001 Leptin-induced nuclear translocation of STAT3 immunoreactivity in hypothalamic nuclei involved in body weight regulation. J Neurosci 21:2413-2424

Huszar D, Lynch CA, Fairchild-Huntress V, Dunmore JH, Fang Q, Berkemeier LR, Gu W, Kesterson RA, Boston BA, Cone RD, Smith FJ, Campfield LA, Burn P, Lee F 1997 Targeted disruption of the melanocortin-4 receptor results in obesity in mice. Cell 88:131-141

Ishida K, Murakami T, Mizuno A, Iida M, Kuwajima M, Shima K 1997 Leptin suppresses basal insulin secretion from rat pancreatic islets. Regul Pept 70:179-182

Islam MS, Sjoholm A, Emilsson V 2000 Fetal pancreatic islets express functional leptin receptors and leptin stimulates proliferation of fetal islet cells. Intl $\mathrm{J}$ Obes Relat Metab Disord 24:1246-1253

Kamohara S, Burcelin R, Halaas JL, Friedman JM, Charron MJ 1997 Acute stimulation of glucose metabolism in mice by leptin treatment. Nature 389:374-377

Kawai T, Hirose H, Seto Y, Fujita H, Saruta T 2001 Chronic effects of different fatty acids and leptin in INS-1 cells. Diabetes Res Clin Pract 51:1-8

Kawaji N, Yoshida A, Motoyashiki T, Morita T, Ueki H 2001 Anti-leptin receptor antibody mimics the stimulation of lipolysis induced by leptin in isolated mouse fat pads. J Lipid Res 42:1671-1677

Kellerer M, Koch M, Metzinger E, Mushack J, Capp E, Haring HU 1997 Leptin activates PI-3 kinase in $\mathrm{C} 2 \mathrm{C} 12$ myotubes via janus kinase-2 (JAK-2) and insulin receptor substrate-2 (IRS-2) dependent pathways. Diabetologia 40:1358-1362

Kieffer TJ, Heller RS, Leech CA, Holz GG, Habener JF 1997 Leptin suppression of insulin secretion by the activation of ATP-sensitive $\mathrm{K}+$ channels in pancreatic beta-cells. Diabetes 46:1087-1093

Kielar D, Clark JS, Ciechanowicz A, Kurzawski G, Sulikowski T, Naruszewicz M 1998 Leptin receptor isoforms expressed in human adipose tissue. Metabolism 47:844-847

Kim MS, Small CJ, Stanley SA, Morgan DG, Seal LJ, Kong WM, Edwards CM, Abusnana S, Sunter D, Ghatei MA, Bloom SR 2000 The central melanocortin system affects the hypothalamo-pituitary thyroid axis and may mediate the effect of leptin. J Clin Invest 105:1005-1011

Kim YB, Uotani S, Pierroz DD, Flier JS, Kahn BB 2000 In vivo administration of leptin activates signal transduction directly in insulin-sensitive tissues: overlapping but distinct pathways from insulin. Endocrinology 141:2328-2339

Kim MS, Small CJ, Russell SH, Morgan DG, Abbott CR, alAhmed SH, Hay DL, Ghatei MA, Smith DM, Bloom SR 2002 Effects of melanocortin receptor ligands on thyrotropin-releasing hormone release: evidence for the differential roles of melanocortin 3 and 4 receptors. J Neuroendocrinol 14:276-282

Klaman LD, Boss O, Peroni OD, Kim JK, Martino JL, Zabolotny JM, Moghal N, Lubkin M, Kim YB, Sharpe AH, Stricker-Krongrad A, Shulman GI, Neel BG, Kahn BB 2000 Increased energy expenditure, decreased adiposity, and tissue-specific insulin sensitivity in protein-tyrosine phosphatase 1B-deficient mice. Mol Cell Biol 20:5479-5489

Korner J, Chua SC Jr, Williams JA, Leibel RL, Wardlaw SL 1999 Regulation of hypothalamic proopiomelanocortin by leptin in lean and obese rats. Neuroendocrinology 70:377-383

Kowalski TJ, Liu SM, Leibel RL, Chua SC Jr 2001 Transgenic complementation of leptin-receptor deficiency. I. Rescue of the obesity/diabetes phenotype of LEPR-null mice expressing a LEPR-B transgene. Diabetes 50:425-435

Kristensen P, Judge ME, Thim L, Ribel U, Christjansen KN, Wulff BS, Clausen JT, Jensen PB, Madsen OD, Vrang N, Larsen PJ, Hastrup S 1998 Hypothalamic CART is a new anorectic peptide regulated by leptin. Nature 393:72-76 
Krude H, Biebermann H, Luck W, Horn R, Brabant G, Gruters A 1998 Severe early-onset obesity, adrenal insufficiency and red hair pigmentation caused by POMC mutations in humans. Nature Genet 19:155-157

Kulkarni RN, Wang ZL, Wang RM, Hurley JD, Smith DM, Ghatei MA, Withers DJ, Gardiner JV, Bailey CJ, Bloom SR 1997 Leptin rapidly suppresses insulin release from insulinoma cells, rat and human islets and, in vivo, in mice. J Clin Invest 100:2729-2736

Kutoh E, Boss O, Levasseur F, Giacobino JP 1998 Quantification of the full length leptin receptor $(\mathrm{OB}-\mathrm{Rb})$ in human brown and white adipose tissue. Life Sci 62:445-451

Lee G-H, Proenca R, Montez JM, Carroll KM, Darvishzadeh JG, Lee JI, Friedman JM 1996 Abnormal splicing of the leptin receptor in diabetic mice. Nature 379:632-635

Legradi G, Emerson CH, Ahima RS, Flier JS, Lechan RM 1997 Leptin prevents fasting-induced suppression of prothyrotropin-releasing hormone messenger ribonucleic acid in neurons of the hypothalamic paraventricular nucleus. Endocrinology 138:2569-2576

Legradi G, Emerson CH, Ahima RS, Rand WM, Flier JS, Lechan RM 1998 Arcuate nucleus ablation prevents fasting-induced suppression of ProTRH mRNA in the hypothalamic paraventricular nucleus. Neuroendocrinology 68:89-97

Li C, Friedman JM 1999 Leptin receptor activation of SH2 domain containing protein tyrosine phosphatase 2 modulates Ob receptor signal transduction.Proc Natl Acad Sci USA 96:96779682

Li JY, Finniss S, Yang YK, Zeng Q, Qu SY, Barsh G, Dickinson C, Gantz I 2000 Agouti-related protein-like immunoreactivity: characterization of release from hypothalamic tissue and presence in serum. Endocrinology 141:1942-1950

Lollmann B, Gruninger S, Stricker-Krongrad A, Chiesi M 1997 Detection and quantification of the leptin receptor splice variants $\mathrm{Ob}-\mathrm{Ra}, \mathrm{b}$, and, e in different mouse tissues. Biochem Biophys Res Commun 238:648-652

Lord GM, Matarese G, Howard JK, Baker RJ, Bloom SR, Lechler RI 1998 Leptin modulates the T-cell immune response and reverses starvation-induced immunosuppression. Nature 394: 897-901

Lupi R, Marchetti P, Maffei M, Del Guerra S, Benzi L, Marselli L, Bertacca A, Navalesi R 1999 Effects of acute or prolonged exposure to human leptin on isolated human islet function. Biochem Biophys Res Commun 256:637-641

Maffei M, Halaas J, Ravussin E, Pratley RE, Lee GH, Zhang Y, Fei H, Kim S, Lallone R, Ranganathan S, et al. 1995 Leptin levels in human and rodent: measurement of plasma leptin and ob RNA in obese and weight-reduced subjects. Nature Med 1:1155-1161

Marks DL, Cone RD 2001 Central melanocortins and the regulation of weight during acute and chronic disease. Recent Prog Horm Res 56:359-375

Maroni P, Bendinelli P, Piccoletti R 2003 Early intracellular events induced by in vivo leptin treatment in mouse skeletal muscle. Mol Cell Endocrinol 201:109-121

Martin-Romero C, Santos-Alvarez J, Goberna R, Sanchez-Margalet V 2000 Human leptin enhances activation and proliferation of human circulating $\mathrm{T}$ lymphocytes. Cell Immunol 199:15-24

Masuda S, Nagao M, Takahata K, Konishi Y, Gallyas F Jr, Tabira T, Sasaki R 1993 Functional erythropoietin receptor of the cells with neural characteristics. Comparison with receptor properties of erythroid cells. J Biol Chem 268:11208-11216

Mercer JG, Hoggard N, Williams LM, Lawrence CB, Hannah LT, Morgan PJ, Trayhurn P 1996 Coexpression of leptin receptor and preproneuropeptide Y mRNA in arcuate nucleus of mouse hypothalamus. J Neuroendocrinol 8:733-735

Mercer JG, Hoggard N, Williams LM, Lawrence CB, Hannah LT, Trayhurn P 1996 Localization of leptin receptor mRNA and the long form splice variant $(\mathrm{Ob}-\mathrm{Rb})$ in mouse hypothalamus and adjacent brain regions by in situ hybridization. FEBS Lett 387:113-116 
Mercer JG, Moar KM, Hoggard N 1998 Localization of leptin receptor (Ob-R) messenger ribonucleic acid in the rodent hindbrain. Endocrinology 139:29-34

Miki T, Liss B, Minami K, Shiuchi T, Saraya A, Kashima Y, Horiuchi M, Ashcroft F, Minokoshi Y, Roeper J, Seino S 2001 ATP-sensitive K+ channels in the hypothalamus are essential for the maintenance of glucose homeostasis. Nature Neurosci 4:507-512

Mizuno TM, Kleopoulos SP, Bergen HT, Roberts JL, Priest CA, Mobbs CV 1998 Hypothalamic pro-opiomelanocortin mRNA is reduced by fasting and [corrected] in ob/ob and db/db mice, but is stimulated by leptin. Diabetes 47:294-297

Minokoshi Y, Kim YB, Peroni OD, Fryer LG, Muller C, Carling D, Kahn BB 2002 Leptin stimulates fatty-acid oxidation by activating AMP-activated protein kinase. Nature 415:339 343

Minokoshi Y, Kahn BB 2003 Role of AMP-activated protein kinase in leptin-induced fatty acid oxidation in muscle. Biochem Soc Trans 31:196-201

Montague CT, Farooqi IS, Whitehead JP, Soos MA, Rau H, Wareham NJ, Sewter CP, Digby JE, Mohammed SN, Hurst JA, Cheetham CH, Earley AR, Barnett AH, Prins JB, O'Rahilly S 1997 Congenital leptin deficiency is associated with severe early-onset obesity in humans. Nature 387:903-908

Morrison CD, Morton GM, Niswender KN, Gelling RW, Schwartz MW 2003 Leptin regulation of hypothalamic NPY and AgRP, but not Socs3, gene expression is dependent on PI3K. Presented at Keystone Symposium on Obesity. Keystone, CO, January 21-26, abstract 126

Morton NM, Emilsson V, de Groot P, Pallett AL, Cawthorne MA 1999 Leptin signalling in pancreatic islets and clonal insulin-secreting cells. J Mol Endocrinol 22:173-184

Muenzberg H, Huo L, Nillni EA, Hollenberg AN, Bjorbaek C 2003 Role of signal transducer and activator of transcription 3 in regulation of hypothalamic proopiomelanocortin gene expression by leptin. Endocrinology 144:2121-2131

Muller G, Ertl J, Gerl M, Preibisch G 1997 Leptin impairs metabolic actions of insulin in isolated rat adipocytes. J Biol Chem 272:10585-10593

Muoio DM, Dohm GL, Fiedorek FT Jr, Tapscott EB, Coleman RA, Dohn GL 1997 Leptin directly alters lipid partitioning in skeletal muscle. Diabetes 46:1360-1363

Murakami T, Yamashita T, Iida M, Kuwajima M, Shima K 1997 A short form of leptin receptor performs signal transduction. Biochem Biophys Res Commun 231:26-29

Murphy B, Nunes CN, Ronan JJ, Harper CM, Beall MJ, Hanaway M, Fairhurst AM, Van der Ploeg LH, MacIntyre DE, Mellin TN 1998 Melanocortin mediated inhibition of feeding behavior in rats. Neuropeptides 32:491-497

Naka T, Narazaki M, Hirata M, Matsumoto T, Minamoto S, Aono A, Nishimoto N, Kajita T, Taga T, Yoshizaki K, Akira S, Kishimoto T 1997 Structure and function of a new STAT-induced STAT inhibitor. Nature 387:924-929

Nillni EA, Vaslet C, Harris M, Hollenberg A, Bjorbaek C, Flier JS 2000 Leptin regulates prothyrotropin-releasing hormone biosynthesis. J Biol Chem 275:36124-36133

Niswender KD, Morton GJ, Stearns WH, Rhodes CJ, Myers MG Jr, Schwartz MW 2001 Intracellular signalling. Key enzyme in leptin-induced anorexia. Nature 413:794-795

O'Rourke L, Yeaman SJ, Shepherd PR 2001 Insulin and leptin acutely regulate cholesterol ester metabolism in macrophages by novel signaling pathways. Diabetes 50:955-961

Okuya S, Tanabe K, Tanizawa Y, Oka Y 2001 Leptin increases the viability of isolated rat pancreatic islets by suppressing apoptosis. Endocrinology 142:4827-4830

Ollmann MM, Wilson BD, Yang YK, Kerns JA, Chen Y, Gantz I, Barsh GS 1997 Antagonism of central melanocortin receptors in vitro and in vivo by agouti-related protein. Science 278:135-138

Ookuma M, Ookuma K, York DA 1998 Effects of leptin on insulin secretion from isolated rat pancreatic islets. Diabetes 47:219-223 
Pallett AL, Morton NM, Cawthorne MA, Emilsson V 1997 Leptin inhibits insulin secretion and reduces insulin mRNA levels in rat isolated pancreatic islets. Biochem Biophys Res Commun 238:267-270

Peiser C, McGregor GP, Lang RE 2000 Leptin receptor expression and suppressor of cytokine signaling transcript levels in high-fat-fed rats. Life Sci 67:2971-2981

Pelleymounter MA, Cullen MJ, Baker MB, Hecht R, Winters D, Boone T, Collins F 1995 Effects of the obese gene product on body weight regulation in ob/ob mice. Science 269:540-543

Peralta S, Carrascosa JM, Gallardo N, Ros M, Arribas C 2002 Ageing increases SOCS-3 expression in rat hypothalamus: effects of food restriction. Biochem Biophys Res Commun 296:425-428

Plut C, Ribiere C, Giudicelli Y, Dausse JP 2003 Hypothalamic leptin receptor and signaling molecule expressions in cafeteria diet-fed rats. J Pharmacol Exp Ther 307:544-549

Poitout V, Rouault C, Guerre-Millo M, Briaud I, Reach G 1998 Inhibition of insulin secretion by leptin in normal rodent islets of Langerhans. Endocrinology 139:822-826

Powis JE, Bains JS, Ferguson AV 1998 Leptin depolarizes rat hypothalamic paraventricular nucleus neurons. Am J Physiol 274:R1468-R1472

Qian S, Chen H, Weingarth D, Trumbauer ME, Novi DE, Guan X, Yu H, Shen Z, Feng Y, Frazier E, Chen A, Camacho RE, Shearman LP, Gopal-Truter S, MacNeil DJ, Van der Ploeg LH, Marsh DJ 2002 Neither agouti-related protein nor neuropeptide Y is critically required for the regulation of energy homeostasis in mice. Mol Cell Biol 22:5027-5035

Rahmouni K, Haynes WG, Morgan DA, Mark AL 2003 Intracellular mechanisms involved in leptin regulation of sympathetic outflow. Hypertension 41:763-767

Roduit R, Thorens B 1997 Inhibition of glucose-induced insulin secretion by long-term preexposure of pancreatic islets to leptin. FEBS Lett 415:179-182

Ridderstrale M, Amstrup J, Hilton DJ, Billestrup N, Tornqvist H 2003 SOCS-3 is involved in the downregulation of the acute insulin-like effects of growth hormone in rat adipocytes by inhibition of Jak2/IRS-1 signaling. Horm Metab Res 35:169-177

Rodriguez VM, Macarulla MT, Echevarria E, Portillo MP 2003 Lipolysis induced by leptin in rat adipose tissue from different anatomical locations. Eur J Nutrit 42:149-153

Rui L, Yuan M, Frantz D, Shoelson S, White MF 2002 SOCS-1 and SOCS-3 block insulin signaling by ubiquitin-mediated degradation of IRS1 and IRS2. J Biol Chem 277:4239442398

Sanchez-Margalet V, Martin-Romero C 2001 Human leptin signaling in human peripheral blood mononuclear cells: activation of the JAK-STAT pathway. Cell Immunol 211:30-36

Scarpace PJ, Matheny M, Shek EW 2000 Impaired leptin signal transduction with age-related obesity. Neuropharmacology 39:1872-1879

Schwartz GJ, Moran TH 2002 Leptin and neuropeptide y have opposing modulatory effects on nucleus of the solitary tract neurophysiological responses to gastric loads: implications for the control of food intake. Endocrinology 143:3779-3784

Schwartz MW, Baskin DG, Bukowski TR, Kuijper JL, Foster D, Lasser G, Prunkard DE, Porte D Jr, Woods SC, Seeley RJ, Weigle DS 1996 Specificity of leptin action on elevated blood glucose levels and hypothalamic neuropeptide $\mathrm{Y}$ gene expression in ob/ob mice. Diabetes 45:531-535

Schwartz MW, Seeley RJ, Woods SC, Weigle DS, Campfield LA, Burn P, Baskin DG 1997 Leptin increases hypothalamic pro-opiomelanocortin mRNA expression in the rostral arcuate nucleus. Diabetes 46:2119-2123

Schwartz MW, Woods SC, Porte D Jr, Seeley RJ, Baskin DG 2000 Central nervous system control of food intake. Nature 404:661-671

Seeley RJ, Yagaloff KA, Fisher SL, Burn P, Thiele TE, van Dijk G, Baskin DG, Schwartz MW 1997 Melanocortin receptors in leptin effects. Nature 390:349 
Segal-Lieberman G, Trombly DJ, Juthani V, Wang X, Maratos-Flier E 2003 NPY ablation in C57BL/6 mice leads to mild obesity and to an impaired refeeding response to fasting. Am J Physiol Endocrinol Metab 284:E1131-E1139

Seufert J, Kieffer TJ, Leech CA, Holz GG, Moritz W, Ricordi C, Habener JF 1999 Leptin suppression of insulin secretion and gene expression in human pancreatic islets: implications for the development of adipogenic diabetes mellitus. J Clin Endocrinol Metab 84:670-676

Shimizu H, Ohtani K, Tsuchiya T, Takahashi H, Uehara Y, Sato N, Mori M 1997 Leptin stimulates insulin secretion and synthesis in HIT-T 15 cells. Peptides 18:1263-1266

Siegrist-Kaiser CA, Pauli V, Juge-Aubry CE, Boss O, Pernin A, Chin WW, Cusin I, RohnerJeanrenaud F, Burger AG, Zapf J, Meier CA 1997 Direct effects of leptin on brown and white adipose tissue. J Clin Invest 100:2858-2864

Spanswick D, Smith MA, Groppi VE, Logan SD, Ashford ML 1997 Leptin inhibits hypothalamic neurons by activation of ATP-sensitive potassium channels. Nature 390:521-525

Spanswick D, Smith MA, Mirshamsi S, Routh VH, Ashford ML 2000 Insulin activates ATPsensitive $\mathrm{K}+$ channels in hypothalamic neurons of lean, but not obese rats. Nature Neurosci 3:757-758

Starr R, Willson TA, Viney EM, Murray LJ, Rayner JR, Jenkins BJ, Gonda TJ, Alexander WS, Metcalf D, Nicola NA, Hilton DJ 1997 A family of cytokine-inducible inhibitors of signalling. Nature 387:917-921

Steinberg GR, Rush JW, Dyck DJ 2002 AMPK expression and phosphorylation are increased in rodent muscle after chronic leptin treatment. Am J Physiol Endocrinol Metab 284:E648-E654

Stephens TW, Basinski M, Bristow PK, Bue-Valleskey JM, Burgett SG, Craft L, Hale J, Hoffmann J, Hsiung HM, Kriauciunas A, MacKellar W, Rosteck Jr PR, Schoner B, Smith D, Tinsley FC, Zhang X-Y, Heiman M 1995 The role of neuropeptide Y in the antiobesity action of the obese gene product. Nature 377:530-532

Szanto I, Kahn CR 2000 Selective interaction between leptin and insulin signaling pathways in a hepatic cell line. Proc Natl Acad Sci USA 97:2355-2360

Takahashi Y, Okimura Y, Mizuno I, Takahashi T, Kaji H, Uchiyama T, Abe H, Chihara K 1996 Leptin induces tyrosine phosphorylation of cellular proteins including STAT-1 in human renal adenocarcinoma cells, ACHN. Biochem Biophys Res Commun 228:859-864

Takahashi Y, Okimura Y, Mizuno I, Iida K, Takahashi T, Kaji H, Abe H, Chihara K 1997 Leptin induces mitogen-activated protein kinase-dependent proliferation of C3H10T1/2 cells. J Biol Chem 272:12897-12900

Tanizawa Y, Okuya S, Ishihara H, Asano T, Yada T, Oka Y 1997 Direct stimulation of basal insulin secretion by physiological concentrations of leptin in pancreatic beta cells. Endocrinology 138:4513-4516

Tartaglia LA, Dembski M, Weng X, Deng N, Culpepper J, Devos R, Richards GJ, Campfield LA, Clark FT, Deeds J, Muir C, Sanker S, Moriarty A, Moore K J, Smutko JS, Mays GG, Woolf EA, Monroe CA, Tepper RI 1995 Identification and expression cloning of a leptin receptor. Cell 83:1263-1271

Thornton JE, Cheung CC, Clifton DK, Steiner RA 1997 Regulation of hypothalamic proopiomelanocortin mRNA by leptin in ob/ob mice. Endocrinology 138:5063-5066

Tsumanuma I, Jin L, Zhang S, Bayliss JM, Scheithauer BW, Lloyd RV 2000 Leptin signal transduction in the HP75 human pituitary cell line. Pituitary 3:211-220

Unger RH, Zhou YT, Orci L 1999 Regulation of fatty acid homeostasis in cells: novel role of leptin. Proc Natl Acad Sci USA 96:2327-2332

Uotani S, Bjorbaek C, Tornoe J, Flier JS 1999 Functional properties of leptin receptor isoforms: internalization and degradation of leptin and ligand-induced receptor downregulation. Diabetes $48: 279-286$ 
Vaisse C, Halaas JL, Horvath CM, Darnell JE Jr, Stoffel M, Friedman JM 1996 Leptin activation of Stat3 in the hypothalamus of wild-type and $o b / o b$ mice but not $d b / d b$ mice. Nature Genet 14:95-97

Vaisse C, Clement K, Guy-Grand B, Froguel P 1998 A frameshift mutation in human MC4R is associated with a dominant form of obesity. Nature Genet 20:113-114

Wang MY, Zhou YT, Newgard CB, Unger RH 1996 A novel leptin receptor isoform in rat. FEBS Lett 392:87-90

Wang MY, Lee Y, Unger RH 1999 Novel form of lipolysis induced by leptin. J Biol Chem 274:17541-17544

Watanobe H, Habu S 2002 Leptin regulates growth hormone-releasing factor, somatostatin, and alpha-melanocyte-stimulating hormone but not neuropeptide $\mathrm{Y}$ release in rat hypothalamus in vivo: relation with growth hormone secretion. J Neurosci 22:6265-6271

Winder WW, Hardie DG 1999 AMP-activated protein kinase, a metabolic master switch: possible roles in type 2 diabetes. Am J Physiol 277:E1-E10

Yeo GS, Farooqi IS, Aminian S, Halsall DJ, Stanhope RG, O'Rahilly S 1998 A frameshift mutation in MC4R associated with dominantly inherited human obesity. Nature Genet 20:111-112

Yaswen L, Diehl N, Brennan MB, Hochgeschwender U 1999 Obesity in the mouse model of pro-opiomelanocortin deficiency responds to peripheral melanocortin. Nature Med 5:10661070

Yoshimura A, Ohkubo T, Kiguchi T, Jenkins NA, Gilbert DJ, Copeland NG, Hara T, Miyajima A 1995 A novel cytokine-inducible gene CIS encodes an SH2-containing protein that binds to tyrosine-phosphorylated interleukin 3 and erythropoietin receptors. EMBO J 14:28162826

Yu WH, Kimura M, Walczewska A, Karanth S, McCann SM 1997 Role of leptin in hypothalamic-pituitary function. Proc Natl Acad Sci USA 94:1023-1028

Zabolotny JM, Bence-Hanulec KK, Stricker-Krongrad A, Haj F, Wang Y, Minokoshi Y, Kim YB, Elmquist JK, Tartaglia LA, Kahn BB, Neel BG 2002 PTP1B regulates leptin signal transduction in vivo. Dev Cell 2:489-495

Zhang Y, Proenca R, Maffei M, Barone M, Leopold L, Friedman JM 1994 Positional cloning of the mouse obese gene and its human homologue. Nature 372: 425-432

Zhao AZ, Shinohara MM, Huang D, Shimizu M, Eldar-Finkelman H, Krebs EG, Beavo JA, Bornfeldt KE 2002 Leptin induces insulin-like signaling that antagonizes cAMP elevation by glucagon in hepatocytes. J Biol Chem 275:11348-11354

Zhao AZ, Huan JN, Gupta S, Pal R, Sahu A 2002 A phosphatidylinositol 3-kinase phosphodiesterase 3B-cyclic AMP pathway in hypothalamic action of leptin on feeding. Nature Neurosci 5:727-728

Zierath JR, Frevert EU, Ryder JW, Berggren PO, Kahn BB 1998 Evidence against a direct effect of leptin on glucose transport in skeletal muscle and adipocytes. Diabetes 47:1-4 